\title{
Türk Spor Basınında Asparagas Haber ve Spor Ekonomisine Etkileri
}

\author{
Mustafa İnce*
}

Karabük Üniversitesi, Safranbolu Meslek Yüksekokulu, Karabük.

$\ddot{O} z$

Basının en önemli işlevi haber ve bilgi vermedir. Basın, bu işlevini yerine getirirken güvenilir olmalıdır. Bu güvenilirliğin basının her alanında uygulanması zorunludur. Ancak basın, bunu farklı alanlarda çeşitli şekillerde ihlal etmektedir. Bu alanlardan biri de spor basınıdır. Spor basını, spor olayların halka duyurma işlevini yerine getiren, tüm dünyada olduğu gibi ülkemizde de geniş kitleleri etkileyen bir güce sahiptir. Günümüzde spora duyulan ilginin her geçen gün artması sonucu büyük bir spor kamuoyu oluşmuştur. Basın, bu kamuoyunun oluşmasında, bilgilenmesinde ve yönlenmesinde büyük pay sahibi olmuştur. Spor basınl, kitleleri daha fazla heyecanlandırmak, sporun aktörlerine ve spor ekonomisine doğrudan veya dolaylı etki etmek ve yön vermek amacıyla olayları bazen abartarak, bazen çarpıtarak bazen de tamamen yalan olarak sunabilmektedir. Bu çalı̧̧mada, spor basınında yer alan "asparagas" haberlerin, spor ekonomisine ne gibi etkileri olduğunun irdelenmesi amaçlanmaktadır. Çalışmada spor medyasında yer alan asparagas haberlerle, gazete satışları, borsa, kulüplerin lisanslı ürün satışları, kombine bilet satışları ve takımları bilinirliği arasında bağlantı olduğu anlaşılmıştır.

Anahtar Kelimeler: Spor Basın, Asparagas Haber, Spor Ekonomisi

\section{Fake News in Turkish Sports Media and its Effects on the Sports Economy}

\section{Abstract}

The most important function of the media is to provide news and information. Media must be reliable while carrying out this function. It is important that this is applied properly at every stage. But, the media has violated reliability itself in many different ways in many fields. One of these areas is the sports media. Sports media releases sport events and news to the public and has a power that affects the masses in Turkey as all over the world. Nowadays, a wide sports public has formed due to the increased interest in sports. Media has been influential in the formation, informing and leading of this sports public. Sports media presents the events sometimes in an exaggerated way, sometimes distorting and sometimes as a total lie in order to excite the masses, to directly or indirectly affect and lead the sports actors and sports economy. In this study, it is aimed to determine the effects of "fake news" on sports economy. In the study, it is reported that there is a connection between the fake news in sports media and the sales of newspapers, shirts, licensed products, tickets and teams' recognition.

Keywords: Sports media, Fake news, Sports economy

\section{GíRiş}

Toplumsal bir olgu olan spor, günümüzde küreselleşen dünyada kitle iletişim araçları ile daha yaygın ve popüler olmuştur. Sporun kitle iletişim araçlarıyla topluma ulaşması, kitlelerin daha fazla ilgisini çekmesi açısından da önem arz etmektedir. Spor görsel, işitsel ve görsel işitsel kitle iletişim araçları sayesinde kitlelere ulaşmakta, bu şekilde insanların ilgisini çekmekte ve toplumun gündeminde kalmasını sağlamaktadır. Sporun günümüzde bu kadar yaygın olmasını ve hızlı gelişmesini sadece içinde barındırdığı insani değerler veya ticari ilişkiler ile açıklamak yeterli 
değildir. Bu durumun oluşmasında kitle iletişim araçlarının da oldukça yüksek oranda pay sahibi olduğu söylenebilir (Özsoy ve diğerleri, 2011: 134). Sporun bu hizlı gelişimine ve dönüşümüne özellikle son iki asırdır kitle iletişim araçları eşlik etmiştir. Kitle iletişim araçları, sporu konu olarak işledikçe ve spor olaylarını gündeme taşıdıkça karşılıklı bir yükseliş yaşanmıştır.

Özellikle 20. yüzyılda medya ve spor arasındaki ilişki oldukça gelişmiştir. Andrews'e göre (Andrews, 2005: 1,2) spor, İngiltere medyasında en hizlı gelişen sektördür. Ortalama olarak günlük gazetelerde 2-3 sayfa spor haberi yer almaktadır. Sporun medyada yer alması giderek yayılmıştır ve spor içeriği artmıştır. 1990'ların sonunda Amerika Birleşik Devletleri'nde 4 büyük yayın kuruluşunda yılda 2.100 saat spor yayını yapılmıştır. Kablolu televizyon ise fazladan 6.000 saat daha spor yayını sunmuştur (Talimciler, 2010: 56).

Spor, yazılı ve görsel medya için hayati bir öneme sahip bir konuma gelmiştir. Spor ve medyanın birbirlerini zincirleme olarak etkilediklerini ve birbirlerinin tamamlayıcı unsuru olduğunu söylemek mümkündür. Spor faaliyetlerinin geniş kitlelere ulaşması için medyaya ihtiyaç duyulurken, toplumun yüksek ilgisinden dolayı medya da spora yer vermektedir. Bu bağlamda zincirleme olarak medya ve spor birbirlerinin çekiciliğini arttırmakta ve karşılıklı bir menfaate dönüşmektedir. Nicholson'a göre (Nicholson, 2006: 10) spor ve medya arasındaki ilişki hem ticari hem de kültürel değerlerin paylaşılması bağlamında değerlendirilebilir. Medya sporu amatör bir yapıdan alarak son derece ticari bir endüstri haline getirmiştir. Bunun yanında spor da medyaya büyük oranda seyirci ve reklam geliri kazandırmıştır (Özsoy ve diğerleri, 2011: 134).

Kitle iletişim araçları yoluyla kitlelere ulaşan spor, toplumların sevgisini kazanmış, kitle iletişim araçları için de büyük bir boşluğu doldurmuştur. Böylece spor ve kitle iletişim araçları birbirleriyle etkileşim içerisinde olmuştur. Kitle iletişim araçlarının içeriğinin aşağı yukarı yarısını spor olayları doldurmaktadır (Döşyılmaz: 1998: 28). Kitle iletişim araçları reyting ve tiraj açısından değerlendirildiğinde de yine sporun rolü büyüktür. Spor olaylarının canlı yayınlanması, spor programları, yorum ve açıkoturum programları, spor haberleri ile gazetelerin spora ayırdıkları sayfalar ve (magazin dâhil) daha birçok spor konulu içerik kitle iletişim araçlarının büyük bir bölümünü oluşturmaktadır.

Böylesine büyük bir endüstri ve içi içe girmiş medya-spor ilişkisi, zaman zaman olay ve olguların farklı boyutlara taşınmasına, hem medyanın hem de sporun diğer aktörlerinin menfaatleri doğrultusunda şekillenmesine sebep olmaktadır. Bu çalışmada spor medyasında yer alan asparagas haberlerin, spor ekonomisi üzerindeki etkisi incelenmektedir.

\section{Spor Kavramı}

Farklı şekillerde tanımı bulunan sporu, insanların bireysel veya toplu olarak fiziki, ruhi ve düşünsel kabiliyetini kendine ve rakibine karşı, önceden belirlenmiş bir düzen içinde genellikle başarı kazanmaya yönelik ve mücadele heyecanını yaşamak 
için yaptığı beden hareketlerinin bütünü olarak tanımlayabiliriz. (İnce, 2016: 448) Geçmişi insanlık tarihi kadar eski olan sporun, çok eski zamanlardan beri gerek ferdi, gerekse toplu olarak yapıldığı bilinmektedir. Yüzyıllar boyunca insanlığın vazgeçemediği bir uğraş olan spor, günümüzdeki anlamıyla, tek başına toplu veya takım halinde yapılan, kendine özgü kuralları, teknikleri olan, bedensel ve zihinsel yetilerin gelişmesini sağlayan, eğitici, eğlendirici uğraşı olarak da tanımlanabilir (Savaş, 1997: 305).

Sporun tarihi eskidir ancak insanların sporla ilgilenme şekilleri giderek değişmiştir. Teknik imkânlar, yaşam koşulları, ihtiyaçlar, spora olan ilgiyi şekillendirmede belirleyici olmuştur. Önceleri saldırı ve savunma amaçlı yapılan zıplama, avcılık, ok ve mızrak atma, yumruk vurma gibi dallardan, atçılık, kızak, kayak vb. alanlara yayılmıştır. Teknolojik ve toplumsal gelişmelerle birlikte spor, bugün, mesleki, ekonomik, politik, sosyolojik, estetik ve fiziki olarak çok farklı işlevleri olan bir konuma yükselmiştir.

Sporun sağlıklı yaşamın vazgeçilmez bir parçası olmasının yanı sıra, insanları ve toplumları kaynaştırma ve yakınlaştırma gibi bir görevi de vardır. Gelişmişlik ve geri kalmışlık farkı, sporda da kendisini ortaya koyar. Gelişmiş ülkeler genellikle sporun her dalıyla ilgilenmekte ve başarılı olmakta iken geri kalmış ülkeler ve sporcuları diğerlerine göre daha az maddi yatırım gerektiren spor dallarında (atletizm gibi) başarı göstermektedirler.

Latince kökenli olan spor sözcüğü, "Delport" ve “Disport" sözcüklerinin kısaltılmış şeklidir. Oyun, oyalanma, işten uzaklaşma anlamlarını taşımaktadır (Balcıoğlu, 2003: 128). Spor kavramı 14. yüzyılda, İngiltere' de başlayan ulusallaşma hareketiyle ortaya çıkmıştır. İngiliz diline girmiş Latince sözcüklerin İngilizleştirilmesi amacıyla başındaki ekler atılınca "disport", "desport" biçimindeki kullanımlardan geriye "sport" kalmıştır. Bir görüşe göre de spor sözcüğü günlük dile, Akdenizli denizcilerin limanda (port) geçirdikleri keyifli yaşantıyı denizdeki güçlüklerle dolu yaşamlarının karşıtı olarak anlatmak için argo niteliğinde kullanmalarıyla girmiştir. Spor, İspanyolca “de porte" (limanda olmak) demektir. 14. yüzyılda gemiler uzun seferlerden sonra limana yanaştı̆̆ında, yükler boşaltılırken denizcilerin limanda çeşitli oyunlar oynadıklarıyla ilgili bilgiler bulunmaktadır. Bu oyunların eğlendirici ve rahatlatıcı nitelikte olmakla birlikte, sertlikler barındırdığ 1 kaydedilmektedir (Özsoy, 2011: 89-90).

Spor olayları bugünkü statüsüne kavuşana kadar çok evrelerden geçmiştir. Özellikle sanayi devrimiyle birlikte 'boş zaman' kavramının ortaya çıkmasıyla spor, giderek profesyonelleşmeye başlamış ve çeşitli dallara ayrılmıştır. Bu dönemde kuralları şekillenmeye ve halk tarafından da öğrenilmeye başlayan spor olayları, daha yakından takip edilmiş ve bizzat iştirak edilen bir duruma gelmiştir. Bireysel olarak boş zaman geçirme, stresten uzaklaşma, toplumsal gerçeklerden kaçş̧, bir gruba ait olma, takdir görme vb. amaçla yapılan spor, giderek bireysel bir uğraş olmanın ötesine geçmiştir. Sporculuk bazında para kazanılan, statü edinilen, tam zamanlı bir mesleğe dönüşmüştür. 
Bugün artık spor, insan sağlığını, toplumsal dayanışmayı ve kaynaşmayı ve sosyal yapılanmayı etkileyen, ana unsurlardan biri hâline gelmiştir. Günümüz insanı bizzat sportif faaliyetlerde bulunarak veya sportif mücadeleleri takip ederek taraftar / izleyici olarak sporla ilgilenmektedir. Spor, yapanlar açısından azımsanmayacak faydaları olan bir uğraştır ve tüm dünyada çok büyük kitleleri peşinden sürüklemektedir (Megep, 2011: 3).

\section{Spor ve Spor Medyası İlişkisi}

Sporun hızlı gelişimine ve dönüşümüne özellikle son iki asırdır kitle iletişim araçları eşlik etmiştir. Kitle iletişim araçları, sporu konu olarak işledikçe ve spor olaylarını gündeme taşıdıkça karşılıklı bir yükseliş yaşanmıştır. Spor alanında meydana gelen olayları ve yaşanan gelişmeleri kitlelere aktarma işlevini yerine getiren medya, günümüzde sporun en önemli unsuru, tamamlayıcısı ve ayrılmaz bir parçası konumundadir.

Dünyada, 19. yüzyılın başlarında kurallar uygulanarak yapılmaya başlanan modern spor dallarını ilgi ile izleyen seyircilerin, bu karşılaşmalar için yapılan değerlendirmeleri ve eleştirileri öğrenmek üzere, gazeteleri okumaya başlamasıyla birlikte gazeteler spor olaylarını sayfalarına taşımış ve spor konusunda bilgili yazarlar da aramaya başlamışlardır. Buna bağlı olarak gazetelerde spor yazılarının sütunlar hâlinde yayınlanmaya başlamasıyla spor yazarlığı gündeme gelmiştir. Yirminci yüzyılın ortalarından sonra İngiltere'de futbol takımları, Amerika'da Boks, Fransa'da güreş profesyonel olarak düzenlenmeye başlanınca seyirci kapasitesi artmış ve ilgi fazlalaşmıştır (Megep, 2011: 4).

Kitlelerin spora olan ilgisi arttıkça başta (ve önceleri) basın olmak üzere tüm kitle iletişim araçları giderek spora yönelmiştir. Çoğu toplumsal olaylarda olduğu gibi, toplumun ilgisini çeken konulara duyarsız kalmayan kitle iletişim araçları, spor olaylarını sıkça gündeme taşımış, haberleştirmiş, işlemiş ve spora ilgi duyan bir kitlenin oluşmasına öncülük etmiştir.

Kitle iletişim araçları yoluyla kitlelere ulaşan spor, toplumların sevgisini kazanmış, kitle iletişim araçları için de büyük bir boşluğu doldurmuştur. Böylece spor ve kitle iletişim araçları birbirleriyle etkileşim içerisinde olmuştur. Kitle iletişim araçlarının içeriğinin aşağı yukarı yarısını spor olayları doldurmaktadır (Döşyılmaz, 1998: 28). Kitle iletişim araçları reyting ve tiraj açısından değerlendirildiğinde de yine sporun rolü büyüktür. Spor olaylarının canlı yayınlanması, spor programları, yorum ve açıkoturum programları, spor haberleri ile gazetelerin spora ayırdıkları sayfalar ve (magazin dâhil) daha birçok spor konulu içerik kitle iletişim araçlarının büyük bir bölümünü oluşturmaktadır.

Spor basınının işlevsel olmasının Sanayi Devrimi ile çakışması, ilk spor gazetelerinin de bu dönemde yayınlanmasına yol açmıştır. İlk spor gazetesi 1838 yılında İngiltere'de Sporting Life adı ile yayınlanmış, bunu 1854 yılında Paris'te yayınlanan Le Sport dergisi izlemiştir (Megep, 2011: 4). Radyoda 1927 yılında BBC'nin canlı yayınladığı İngiltere - Galler rugby maçı dünyada canlı yayınlanan ilk spor olayı 
olmuştur. Televizyonda ise 17 Mayıs 1939'da Princeton - Columbia baseball maçı ilk spor canlı yayını olmuştur (Talimciler, 2010: 54-55). Ve bu tarihlerden sonra artık canlı yayınların sayısı artmıs, aynı anda birden fazla televizyon kanalı tarafından yayınlar yapılmış, firmalar spor olaylarına sponsor olmaya başlamışlardır. Canlı yayınlar geçmişte olduğu gibi bugün de sporun ilgi çekmesine sebep olmuştur. İzleyiciler açısından müsabakaların 'şimdi gerçekleşiyor' ve 'yeni' olması, ilginin artmasını sağlamaktadır. Önceleri spor olaylarının başarısı kritik bir alan olarak değerlendirilmezken 1990'lara gelindiğinde ise bu durum tamamen değişmiştir. Örneğin 1990'ların sonunda Amerika Birleşik Devletleri'nde 4 büyük yayın kuruluşunda yılda 2.100 saat spor yayını yapılmıştır. Kablolu televizyon ise fazladan 6.000 saat daha spor yayını sunmuştur (Talimciler, 2010: 56). Bu da, kitle iletişim araçları ile sporun gün geçtikçe daha çok iç içe olduğu anlamına gelmektedir.

Türkiye'de ise spor ve kitle iletişim araçlarının ilişkisi cumhuriyetin ilk yıllarına uzanmaktadır. Cumhuriyetin ilanından sonra özellikle yazılı basın açısından spor alanında hareketlenmeler olmuş, spor yazıları gazetelerde ve dergilerde yer almaya başlamıştır. Hatta sadece spor alanında dergiler yayınlanmaya başlanmıştır.

Cumhuriyet ilan edildikten sonra spor haberleri giderek önem kazanmaya başlamıştır. Cumhuriyet ve Akşam gazetelerinin ilk sayfasında spor haberleri yer almaya başlamıştır. Türk spor basını tarihinde birinci sayfadan spor haberi yayınlayan ilk gazete Ali Naci Karacan'ın sahibi olduğu Akşam gazetesi olmuştur. (Atalay 2004: 90). 1924 yılında Paris Olimpiyatları'na hazırlanan Türk Milli Futbol Takımı'nın bir fotoğrafı Cumhuriyet gazetesinin birinci sayfasında yer almıştır. Cumhuriyet gazetesinin kurucusu Yunus Nadi, , 1924 yılında çıkarmaya başladığı gazetenin sunuş yazısında amaç, şekil ve mesleğine ait esasları ve gazetesinin özelliklerini belirtirken, "Gazetenin iktisat ve spor sütunları en yetkili uzmanlarca hazırlanacaktır" ifadesini kullanmıştır. Gazetenin dördüncü sayfası ikişer sütun halin-de spora ayrılmıştır (İnuğur, 1992: 67).

Cumhuriyetin ilk yıllarından itibaren gazetelerde yer almaya başlayan spor olaylarına Özellikle de 1950'li yıllardan itibaren günlük gazeteler ve radyolar daha fazla ilgi göstermiştir. Örneğin Hürriyet gazetesi 1948 Londra olimpiyatlarına özel muhabir göndermiş, gelişmeleri yakından takip etmiş ve okuyucularına aktarmıştır. Gazetenin o günlerdeki nüshaları elden ele dolaşmıştır.

Türk basınında spor konusundaki ilk yazıya 14 Mart 1891 tarihli Servet-i Fünûn Dergisinde yayınlanan eskrim konulu Ali Ferruh Bey'in yazısıdır (Çetin, 2015: 153). İlk spor dergisini ise daha sonraları Burhan Felek ismiyle tanınacak olan Üsküdarlı Burhanettin Bey, 28 Eylül 1910” da “Futbol” adıyla çıkartmıştır (Çakır, 2008: 193). Futbolun yanı sıra, diğer sporlara da yer veren dergi 6 sayı çıkabilmiştir. İkinci spor dergisi 1911'de çıkan “Terbiye ve Oyun"dur. Bu dergide Selim Sırn Tarcan eğitim ağırlıklı yazılar yazmıştır (Altın, 2016: 102). 1934 yılında spor basınında yepyeni bir uygulama başlatılmıştır. Zamanının en iyi futbol hakemlerinden biri olan İzzet Muhiddin (Apak), çalışmakta olduğu "Haber" isimli akşam gazetesinin son sayfasını tamamen spora ayırarak, günümüze dek uzayıp gelen bir sistemin kurucusu ve öncüsü 
olmuştur. Bu uygulamayla birlikte "gazeteleri arka sayfalarından okuma" alışkanlığ da başlamıştır. Türk spor basınında 1930'lu yılların sonlarında yaşanan en önemli gelişme profesyonel spor yazarlarının ortaya çıkması olmuştur. Özellikle günlük gazeteler, spor olaylarını layıkıyla izleyebilmek ve okuyucularına aktarabilmek amaciyla kadrolarında salt sporla görevli profesyonel yazarlara da yer vermek zorunda kaldılar. Yine bu dönemde, gazeteler, İstanbul dışındaki önemli şehirlerde yapılan spor faaliyetlerini izleyebilmek için de yurdun çeşitli yörelerinde özel muhabir ve yazarlar görevlendirmeye başladılar. 1940'lı yıllar sporun günlük gazetelerde yerini sağlamlaştırdığı yıllar oldu. Önce Vatan gazetesi, arka sayfasının tamamını spora ayırdı (Megep, 2011: 5). Ardından Cumhuriyet, Akşam ve Son Posta gibi gazeteler spora ayırdıkları sütun sayılarını arttırarak bu gelişmeye ayak uydurmaya çalıştılar.

Bu gün anladığımız manada spor ile kitle iletişim araçlarının ilişkileri ise özel televizyon kanallarının yayın hayatına başladığı 1990'lı yıllardan itibaren yoğunlaşmıştır. 1980'li yıllarda altın yıllarını yaşayan spor basınının da 1990'lı yıllardan itibaren çeşitlendiğini ve spor üzerine yayın yapan günlük gazete sayısının bu dönemde arttığını gözlemlemek mümkündür. Günümüzde gelişen teknoloji ile birlikte iletişim olanaklarının çeşitlenmesi, spor haberlerini kitlelere hızlı, çeşitli, fazla miktarda ve detaylı olarak ulaştırılmasını sağlamış, kamuoyunun spora olan ilgisi bu sayede artmıştır.

Daha fazla okuyucuya sahip olmak ve satışları artırmak amacıyla günümüzde günlük spor gazeteleri, okuyucularına spor haberlerinin dışında her gün at yarışı ve iddia tahminlerinin yer aldığı çok sayıda sayfa ve ekler sunmaktadır. At yarışı ve 'iddaa' tahmininde bulunan yazarların duyuruları 1. sayfaların manşet üstü tabir edilen görünür yerlerinde ilgi çekici ve abartılı bir şekilde verilmektedir. Gazeteler, 'iddaa' ile ilgili sayfalarında 'Bugün Fotospor alan yarın köşeyi döner', 'Bombayı patlatıyoruz', 'Kral Tanju banko veriyor', 'Efsane menecer Sinan Engin'den müthiş tüyolar', 'Nakit para isteyen var mı?' şeklindeki çarpıcı sloganlarla okuyucu çekme ve tiraj artırma yarışına girmiştir (Özsoy, 2011: 95).

Spor gazetelerinin sayfalarının üstünde içerikle ilgili klişe ifadeler göze çarpmaktadır. Buna göre hemen her gazetede Galatasaray, Fenerbahçe, Beşiktaş ve Trabzonspor'un 1 ya da 2 sayfası bulunmaktadır. Bunun dişında "1. Lig", "2. Lig", "Türkiye Ligleri", başlığı altında diğer futbol haberleri yer almaktadır. "Hayatın içinden", "Aktüel haber" başlıkları altında 1 veya yarım sayfa olarak futbol dışındaki diğer spor branşlarından haberlere de az da olsa yer verilmektedir. Spor gazeteleri, "poster" duyurusuyla büyük kulüplere yeni transfer olan futbolcuların tam sayfa fotoğraflarını, belirli dönemlerde fikstür ve takım fotoğraflarını yayınlamaktadır (Özsoy, 2011: 95). Bütün bu uygulamalar yine satışları artırmak, okuyucuları etkilemek ve heyecanlandırmak maksadıyla yapılmaktadır.

Dünyada olduğu gibi Türkiye'de de en yaygın spor dalı olan futbol, kitleler tarafından büyük ilgi görmüş, bu ilgi doğrultusunda da medyada geniş yer bulmuştur. Futbol bir taraftan ekonomik değer bakımından birçok endüstri alanını geride bırakan bir sektöre dönüşürken, diğer taraftan spor basını bu sistemin içerisinde daha fazla 
etkin olmak istemektedir. Futbolun büyük bir endüstriye dönüşmesi ve medyada işlenmesi, kamuoyunun daha fazla sporla (özellikle de futbolla) ilgilenmesine yol açmıştır, Türkiye'de spor ile futbol neredeyse eş anlamlı olarak kullanılmaya başlanmıştır. Türkiye Futbol Federasyonu'nun yaptırdığı Futbol Kamuoyu Araştırması'na göre (2005) Türkiye'de spor denince insanların \% 52,7' sinin aklına futbol gelmektedir.

Türkiye'de spor geniş bir yelpazesi olan bir kavram haline gelmiştir. Spor medyası da bu durumda kendine düşen payı almaktadır. Spor medyası, sporu takipte önemli bir paya sahip olup, medyanın insanlar üzerindeki gücünü fazlasıyla fark ettirmektedir. Spor basını sayesinde, kamuoyu artık karşılaşma sonrası verilen kararları, takımın, sporcunun ve hatta hakemlerin performansını kurallar çerçevesinde, eleştirel gözle yorumlayabilecek düzeye gelmiştir. (Ünsal ve Ramazanoğlu, 2013: 4344). Ancak spor basını bununla da yetinmemiş kitleleri daha fazla etkilemek, heyecanlandırmak ve kendilerine bağlamak adına daha fazlasını yapmaya çalışmıştır.

\section{Asparagas Haber}

Basının toplumu bilgilendirmede ve yönlendirmede rolü büyüktür. Teknolojik gelişmelerin baş döndürücü bir ivme kazandığı günümüzde, yazılı ve görsel basının önemi giderek artarken; tarafsız gazetecilik ilkelerinin korunması "vazgeçilemez bir şart" haline gelmiştir. Basında tarafsızlık kavramı, öncelikle, haber ve yorum işlevleri açısından, basının tarafsızlığını; yani objektif olması gerekliliğini akla getiriyor. 4'üncü güç, hatta belki de 1'inci güç olarak kabul edilen basının, demokrasiler içerisindeki, halkı bilgilendirmenin ötesinde halk adına idareyi denetleme görevi, ancak bu tarafsızlık şemsiyesi ile mümkündür. Ne yazık ki, Türk Basının, demokratik idarelerde büyük güçler atfedilen özelliğini hakkıyla yerine getiremediğini, bunun sebebinin de; Türk Basının içerisinde bulunduğu "sübjektiflik açmazı" olduğunu görüyoruz (Barut, 2000: 145-162).

Yazılı ve görsel işitsel basın, izleyicilerinin farklı ilgi ve meraklarını tatmin etmek için, değişik haber yaklaşımları uygulamaktadır. Bu bazen yanlı haber, bazen abartılı haber, bazen de haberle yorumun karıştırılması şeklinde olabilmektedir. Ancak basının, özellikle de spor basınını bunun da ötesine geçerek, dedikoduları, söylentileri, kendi arzu ettiklerini, hatta gerçekleşmesi neredeyse imkânsız olan bazı olayları dahi haberleştirdikleri görülmektedir. Oysa tam aksine haberin yayınlanabilmesi için olmazsa olmaz koşullardan birisi kesinliktir. Anlaşılır bir haber sunmak için, açıklık ve sadelik ne kadar gerekliyse, okuyucunun / izleyicilerin inanmasını sağlamak bakımından kesinlik de o kadar gereklidir. Kesin ifade, ikna etmek ve inandırma etkenlerini de taşıdığından, haberin özünü oluşturur, anlaşılmasını kolaylaştırır ve haberi güçlendirir. Oysa dedikodudan, söylentiden hatta yalandan ibaret olan ve herhangi bir dayanağı bulunmayan yazıları asparagas (uydurma) haber olarak nitelendirebiliriz. Bu tarz haberler kitleleri kandırmanın yanı sıra spor basınını itibarsızlaştırmakta ve basına olan güvenini derinden sarsmaktadır.

Asparagas, gerçek olmayan, masa başında uydurulan, yalan haber, uydurma haber demektir. Hiçbir gerçekliği olmayan kişilerin veya firmaların rant sağlamak 
amacıyla uydurduğu sahte haberlerdir. Türkçe literatürde "para az gerisi gaz" denilerek üretilmiş ve asparagas adlı derme çatma bir kulübede yaşayan insanların öyküsünü işleyen bir haberle birlikte ortaya çıkmış ve kısa zamanda bir gazetecilik terimi olarak kullanılmaya başlanmıştır (Vikipedi, 6 Mart 2014). Asparagas haber, Türk Dil Kurumu (TDK) tarafından şişirme haber olarak tanımlanmaktadır. Asparagas sözcüğ̈̈; aynı zamanda Kuşkonmaz bitkisinin İngilizce (asparagus) okunuşu, yeşil rengin tonlarına İngilizce' de verilen ad anlamina gelmektedir.

Haberciler haber oluştururken çok dikkatli, özenli ve hassas olmak durumundadırlar. Gazeteciyim diyen aklına geleni haber yapamaz veya haber diyerek bir olayı çarpıtamaz, hatta ölçüsü dışında büyütemez, bu gibi olaylarda hep mesleğin kuralları gündeme gelir. Gazeteler normal şartlarda sadece okuyucularına karşı sorumludurlar. $\mathrm{Bu}$ sorumluluk yerine getirilmediğinde, yani asparagas haber üretildiğinde ve yayınlandığında (kişilik haklarının ihlali, hakaret vb. durumlar hariç) bunu önleyecek bir kurum veya yasa mevcut değildir. Bu ancak basının kendi ahlaki ve vicdani sorumluluğundadır.

Asparagas haber günümüz basınının genel sorunudur. İdeolojik, siyasi ve ekonomik açıdan belirli kişi veya guruplara bağlı ya da bu grupların düşüncesini yayma maksadıyla yayın yapan basın, kendi doğrularını oluşturmakta ve kendi çıarlarına hizmet edebilecek haber ve bilgileri toplamakta, düzenlemekte hatta üretmektedir. $\mathrm{Bu}$ anlayış basının güven kaybetmesine ve itibarsızlaşmasına neden olmaktadir.

Asparagas haber basınımızda o kadar sıradanlaşmıştır ki bir gazete asparagas haberi manşet yapıp daha sonra aynı haberin bir cevap niteliğinde "ders vermek amacıyla" yapıldığını belirtebilmektedir. Takvim Gazetesi 18 Haziran 2013 günkü sayısında, manşetten "Kirli İtiraf" başlığıyla verdiği haberin spotunda şöyle yazıyordu; "Gezi eylemlerini çarpıtarak Türkiye'yi savaş bölgesi gibi gösteren CNN International' in ünlü sunucusu Christiane Amanpour Takvim' e konuştu: Her şeyi para için yaptık." Gazete haberle ilgili detay ve Christiane Amanpour' la yapılan röportaj1 verdikten sonra, 14 . sayfada haberin devamının sonuna not olarak şu cümleyi ekliyor; "Not: CNN, Gezi Parkı olaylarını tüm dünyaya yalanlarla duyurdu. Biz de affınıza sığınarak CNN'in anlayacağı dilden bir asparagas haber yaptık. Mevlüt Yüksel'in Christiane Amanpour röportajı gerçek dışıdır..." Bu ve benzer olayları basınımızda sık sık görmek mümkündür.

\section{Spor Basınında Asparagas Haber}

Asparagas haberleri basının her alanında görmenin mümkün olduğundan yukarıda bahsetmiştik. Yalan veya abartılı haberleri, siyasi, ekonomi, güncel, magazin haberlerinde de görüyoruz. Ancak spor haberciliğinde durum biraz daha farklıdır. Günlük gazetelerde spor servislerine ayrılan 3-4 sayfalık yerin, spor haberleriyle doldurulması istenmektedir. Ortalama 16 sayfa yayınlanan günlük spor gazetelerinin işi çok daha zordur. Bu açıdan bakıldığında günlük olarak bu kadar sayfanın spor haberleriyle doldurulması güçtür. Çünkü spor haberi denince bizde genellikle futbol anlaşılmaktadır. Bu zorunluluk spor basınını, sporla ilgili haberleri abartma, çarpıtma ve yalan haber üretmeye elverişli hale getirmiştir. 
Türkiye'de ve Avrupa'nın birçok ülkesinde spor gazetelerinin yaşadığı en büyük sorunlardan biri, transfer pazarındaki asparagas (yalan) haberlerdir. Her geçen yıl daha da büyüyen bu sorun, bazen sporcuların menajerlerinden, bazen kulüplerden, bazen de gazetelerin bizzat kendilerinden kaynaklanmaktadır.

Asparagas haberler özellikle Avrupa'da futbolun, yaşamın bir parçası durumuna geldiği ve sporun dişında büyük bir ekonomik gelirin elde edildiği ülkelerden İtalya ve İspanya'daki spor gazetelerinin sıkça başvurduğu yöntemlerden biridir. Özellikle futbolcu transfer pazarında giderek daha da büyüyen asparagas haber yapma sorunu tüm spor kamuoyunu etkilemektedir. Ülkemizde de futbola olan ilginin artmasıyla birlikte gündem belirlemek, daha fazla okuyucuya ulaşmak, kitleleri heyecanlandırmak ve bunun sonucunda bir çıkar elde etmek amacıyla asparagas haber spor basınının sıkça başvurduğu bir yöntem haline gelmiştir.

Değişen teknolojik ve ekonomik koşulların da etkisiyle spor basınında ciddi bir sorumsuzluk ortaya çıkmış ve medya için yalan haber yapmak normal olarak görülmeye başlanmıştır. Medyanın bu sorumsuz tutumu karşısında gazetelere ve gazetecilere olan güven ve itibar da fazlasıyla zedelenmiştir. Gazetecilerin eskiden büyük bir saygınlığa sahip olduğunu TSYD eski Başkanı Necim Tanyolaç bahisci.com adlı sitede şöyle açıklıyor; "Bizim zamanımızda Cumhurbaşkanları bile servisimize gelirdi. Kulüp başkanların bir araya getirmek istediğimizde, karşımızda ceketlerinin önünü iliklerlerdi. Habercilik ve habercilikteki dürüstlük en büyük silahımızdı. Her gün atlatma haber verebilmek için servis seferber olurdu. Biz gazeteciliğin en yorgun savaşçılarıydık. Yalan habere de bir gün olsun tenezzül etmedik."

Tanyolaç, aralarına sonradan katılan, tuttukları takımlara yaranabilmek adına, yorumculuklarını çirkinleştirenler yüzünden, gerçek basın emekçilerinin kenara itildiğini, ortamın kavga edenlere, aşağılayıcı sözlerle sporcuları karalayanlara kaldığını belirtirken, "Ekmek yediğimiz teknenin içinden, o tekneyi delmeye çalışmak, ihanetle eşdeğerdir. Gazeteci, kalemini menfaati için kullandığında bitmiştir. Saygınlığı kalmamıştır. Onları aramızda bulunduran, bir kartvizitle işe aldıran patronlar ve genel yönetmenler, reyting canavarının esiri kişilerdir. Bu mesleğe yazık ettiklerinin farkına vardıklarında ise artık arkalarına bakamazlar. Çünkü geride sadece yıkıntı görürler." diyerek, günümüz spor gazeteciliğinin yarasına da adeta parmak basıyordu.

Aslında spor basınını yanlı ve yalan haber yapmaya yönlendiren bir başka unsurun da torpille işe yerleştirmeler olduğunu göz ardı etmemek gerekir. Bu konuda Öcal Uluç şunları söylüyor; "Ben spor yazarı olarak mutlu değilim. Biz hâlâ kimliğimizi arıyoruz" diyerek özeleştiride bulundu. Öcal'a göre spor yazarı, sporun gereğini yerine getirmeli. Sporun tek branşında iyi olmak spor yazarı olmak için yeterli değil. Spor yazarlığının bu noktaya gelmesinde suç spor müdürlerinindir. "Eskiden atletizm manşet olurdu, bisiklet manşet olurdu. Şimdi spor sayfalarında kolaycılığa kaçıyoruz. İki tane şöhretli futbolcunun imzasını koy gitsin. Bayrağı çok iyi ellerden aldık ama çok iyi ellere teslim edemedik" (Kola ve Kılıç, 2014: 3).

Türkiye'de gazete ve televizyonlar, futbol sayesinde yüksek tiraj ve reyting alıyor. Bu yüzden spor medyası da hem önem kazanıyor hem de el üstünde tutuluyor. 
Spor medyasının en büyük malzemesi ise 4 büyükler olarak adlandırılan Fenerbahçe, Galatasaray, Beşiktaş ve Trabzonspor'dur. Ardından A Millî Takım ve diğerleri geliyor. Her gazetenin Fenerbahçe, Galatasaray, Beşiktaş ve Trabzonspor'u takip eden en az bir muhabiri ve yazarı var. Kulüp muhabirleri hemen her gün bir haber yapıyor. Gündeme damgasını vuran asparagas haberler de buna dahil. Bu haberler kimi zaman o kadar gündemde tutuluyor ki, kulüpler bazen bu haberler karşısında resmî internet sitelerinden şöyle bir duyuru yapmak zorunda kallyorlar: "Bugün bir gazetede kulübümüzle ilgili çıkan şu haber tamamen asılsızdır." Bazen de bir futbolcu kendi internet sitesinden benzer açılama yapmak durumunda kalıyor; "Hakkımda çıkan şu haberler gerçeği yansıtmamaktadır."

\section{Spor Basınında Asparagas Haber Örnekleri}

Spor basınında yer alan asılsız, abartılı ve kaynağı belli olmayan haberlerin tamamını burada işlemek mümkün değildir. Spor basınında çıkan özellikle izleyiciyiokuyucuyu heyecanlandırmak ve bundan bir çıkar sağlamak maksadıyla son yirmi yılda farklı gazetelerde yer alan haberlerden asparagas olarak nitelendirilebilecek haberlerin bir kısmı ele alınmıştır.

8 Haziran 1998'de Hürriyet Gazetesi'nde yayınlanan, Esat Yilmaer'in, Chicago Bulls oyuncularının takıldığ barda onlarla yaptığ 1 sohbeti aktaran röportaj / haberin girişi, “NBA şampiyonluğu için Utah Jazz'la final serisi maçlarına çıkan Chicago Bulls'lu yıldızlar, Türkiye'deki transfer rakamlarına inanamadı. Jordan, İbrahim Kutluay'ın aldı ̆̆ transfer ücretini duyunca, '- Dalga mı geçiyorsun' derken yüksek rakamları eleştirdi." şeklinde verilmişti. Röportaj haberin uydurma olduğu anlaşıldı (Hürriyet, 8 Haziran 1998). Bu haberle Hürriyet, okurlarına, dünyanın en ünlü sporcularına ulaşabilecek ve onlarla röportaj yapabilecek güçte olduğunu vermeye çalışmıştır.

18 Temmuz 2006 tarihinde Türkiye gazetesinde yer alan Emre Bol imzalı ve "Abramovich'le pazarlık" başlıklı bir haberde Shevchenko'nun 100. yıl bombası olarak Fenerbahçe'ye transfer edileceği yazıyordu. Haber şöyle aktarılmıştı; "Inanılması güuc, yazması daha da güç. Daha bir buçuk ay önce 7 yıllık İtalya kariyerini noktalayarak yaklaşık 30 milyon sterline (yaklaşık 86 milyon YTL) Rus dolar milyarderi Roman Abramovich'in takımı Chelsea'ye geçen Ukraynalı Shevchenko'nun 100. yıl bombası olarak F.Bahçe'ye transfer edileceği iddiası ortalı̆̆ı sarstı. Abramovich'le Moskova'da bir araya gelen Başkan Aziz Yıldırım'ın uzun pazarlıklar sonucunda Anelka'yla Shevchenko'nun kiralık olarak karşılıklı takası konusunda anlaştığı ifade edildi (Türkiye, 18 Temmuz, 2006). Hiçbir zaman gerçekleşmeyen bu transfer haberiyle Türkiye gazetesi okuyucularını meraklandırmayı ve heyecanlandırmayı hedeflemiştir.

Takvim Gazetesinin 28 Haziran 2013 Cuma günkü sayısında "Beşiktaş'a Dev Transfer" başlığıyla verilen haberde Beşiktaş'ın, kulüp üzerindeki kasvetli havayı dağıtmak için Tottenham'ın golcüsü Adebayor' u liste başına aldığı haberi yer alıyordu. Haber, “Tottenham'da forma giyen 29 yaşındaki yildiz ismi transfer etmek isteyen yönetim, bu oyuncunun bonservisinin ve yıllık ücretinin bir kısmını sponsorla çözmeye çalışacak. İngiliz kulübüyle iki yıl daha sözleşmesi bulunan Adebayor'u renklerine katmak için siyahi oyuncuyla görüşecek olan yönetim, bu transferi gerçekleştirerek hem UEFA sürecini 
unutturacak, hem de forma ve kombine satışlarına ilgiyi artırmaya çalışacak. Adebayor'u Türkiye'ye gelmesi için hatırı sayılır miktarda bir para ödemeyi planlayan Beşiktaş Yönetimi, takım içindeki mali dengeleri bozmamak için bu paranın bir kısmını, sponsorlara ödeteceği iddia edildi. (Takvim, 28 Haziran, 2013)" Şeklinde verilmişti. Kaynağı belli olmayan bu haberin bahsettiği transfer Beşiktaş adına gerçekleşmemişti. Haberde de belirtildiği gibi asıl amaç, forma ve kombine satışlarını artırmaya yönelikti.

Kaynağı belirsiz, temeli olmayan sınırsız ve sorumsuz habercilikte çok ilginç bir haber de internet medyasında ortaya çıkmıştı. İspanya'nın yüksek tirajlı spor gazetelerinden Marca, 10 Ekim 2013 tarihinde internet sitesinden yayınladığ Galatasaray teknik direktörü Roberto Mancini'nin Real Madrid'in Fransız yıldızı Karim Benzema'yı kadrosunda görmek istediğini okuyucularına duyurdu. Marca, haber kaynağı olarak Malatya'nın yerel gazetesi "Malatya Güncel" i gösterdi. 11 Ekim 2013 tarihli Foto Maç gazetesi de Marca'nın haberini kaynak alarak "İspanyol basını Benzema'nın Galatasaray'a transfer olacağını yazdı" şeklinde haber yaptı (Fotomaç, 11 Ekim 2013). Ortaya atılan yalan haber elden ele dolaşıyor, kitlelerde heyecan yapması isteniyordu.

AMK spor gazetesinin internet sitesinde 31 Aralık 2013 tarihinde yayınlanan haberde Ronaldinho'nun Beşiktaş'la anlaştığı yazıldı, Haberde; “Ronaldinho'nun menajeri ve ağabeyi olan Assis, İstanbul'da Beşiktaş İkinci Başkanı Ahmet Nur Çebi'yle görüştü. Vatan'ın haberine göre, Siyah-beyazlılar, Ronaldinho ile iki yıllı̆̆ına anlaştı. Brezilyalı yıldızın yıllık 6 milyon euro ücret alacağı öğrenildi." Bu haber Beşiktaş'ın Resmi İnternet Sitesi'nden yalanlandı (AMK, 31 Aralık 2013) AMK'nın Vatan gazetesine dayandırarak verdiği haberin Beşiktaş'ın resmi sitesinden dahi duyurulduğu yazıyordu. Haberde kesin anlaşma yapıldığı yazıyor, hatta görüşme detaylarına yer veriliyordu. Ancak Ronaldinho Beşiktaş'la anlaşmamıştı.

27 Temmuz 2013 günü Fotomaç' in Gazetesinde ve internet sitesinde yayınlanan "Cardozo Bugün Geliyor!" başlıklı haberde; "Sabah.com.tr'ye konuşan F.Bahçe'nin iki numarası, camianın heyecanla beklediği müjdeyi işte böyle verdi: Cardozo transferi 24 saat içinde açıklanacak. Fenerbahçe, sadece Avrupa'da değil tüm dünyada konuşulacak transferlerden birini gerçekleştirdi. Oscar Cardozo için Benfica ile haftalardır sıkı pazarlık halinde olan Fenerbahçe sonunda istediğini elde etti ve Paraguayh golcüyü bünyesine katmayı başardl. Fenerbahçe Başkan Vekili Abdullah Kiğılı dün saat 16.30'da büyük müjdeyi dünya futbol kamuoyuna duyurdu. sabah.com.tr'ye özel bir açılama yapan Kiğıll, "Cardozo transferi 24 saat içinde açıklanacak. " diye konuştu. Şeklinde verildi. Haberde Cardozónun alacağı ücret ve ödeme şekli de detaylı bir şekilde verilmişti (Fotomaç, 27 Temmuz, 2013). Haberde transferin kesin olarak gerçekleştirildiği yer alıyordu. Ancak Cardozo Fenerbahçe ile anlaşmamıştı.

$\mathrm{Bu}$ ve benzer örnekleri çoğaltmak mümkündür. Spor basınında çıkan bu tarz haberlerin özellikle transfer dönemlerinde arttığı göze çarpmaktadır. Liglerin bitmesiyle satışları azalan gazetelerin bu açığı kapatma çabası sonucu, özellikle spor gazetelerinde asparagas haberlerin arttığı da gözlenmektedir. 


\section{Spor Basını ve Spor Ekonomisi Arasındaki İlişki ve Asparagas Haberlerin Spor Ekonomisine Etkileri}

Spor alanındaki gelişmelerden spor endüstrisi ve spor ekonomisi, doğrudan veya dolaylı olarak etkilenmektedir. Özellikle futbolla ilgili gelişmeler, kulüplerin borsadaki değerinden, lisanslı ürünlerin satışına, kombine kart gelirinden marka bilinirliğine kadar birçok konuda etkili olmaktadır. Kulüpler de transfer çalışmalarında bu ekonomik unsurları göz önünde bulundurmaktadırlar. Örneğin 2012-2013 sezonunda Galatasaray, Didier Drogba ve Wesley Sneijder transferinden sonra 46 bin kombinenin tamamını satmış ve 75 milyon dolar gelir elde etmişti. Yine o sezon 405 bin forma satışıyla 25 milyon Lira kazanmıştı (Çevrimiçi, milliyet.com.tr.) Oysa Galatasaray bir önceki sezonda 20 bin kombinede kalmış, Drogba ve Sneijder'in transferleriyle bu rakamı 40 bine çıkarmayı hedeflemişti. Bu iki transfer sayesinde ise kombinelerin tamamı (46 bin) satıldı (Çevrimiçi, fanatik.com.tr). Aynı dönemde Beşiktaş ise önemli bir transfer yapamamış ve 2011 yılı Temmuz ayında 14 bin kombine satmış olmasına rağmen, 2012 yılının aynı döneminde sadece 2 bin 500 adet kombine satabilmişti (Çevrimiçi, sabah.com.tr). Bursaspor'da da önemli bir transfer yapılamaması kombine satışlarına yansıdı. Bursa Hâkimiyet Gazetesi'nin 26 Temmuz 2012 günkü sayısında yer alan habere göre 2010 yılında Şampiyon olan Bursaspor, kombine için 19 bin 445 koltuk ayırmasına rağmen 9-23 Temmuz tarihlerinde sadece 821 adet kombine satılmıştı. Bir önceki yılda da sadece 4 bin kombine satıldı. Görüldüğü üzere takımların taraftarları yıldız oyuncu transferlerine göre kombine almaya karar vermektedirler.

Spor oyunlarının önemli aktörlerinden biri olan sponsorlar da, sponsor olacakları takımlara önemli maddi destek sağlamaktadırlar. Sponsorlar, destek verecekleri takımları belirlerken takımın taraftarları, marka değeri, bilinirlik, transferler vb. unsurları dikkate almaktadırlar. Türk Telekom Galatasaray'a yıllık 15 milyon dolar (10 yılda 150 Milyon Dolar) sponsorluk bedeli ödeyeceğini açıklamıştı. Daha çok basketbola yatırım yapan Garanti Bankası ise son 10 yılda spora 70 Milyon dolar para aktardı (Çevrimiçi, hürriyet.com.tr). Öte yandan liglerin yayın gelirleri, reklamlar, Avrupa kupalarından elde edilen gelirler de dikkate alındığında oldukça büyük bir ekonomiden söz ediyoruz. Türkiye' de spor ekonomisinin boyutu 700 milyon Avroyu aşmış durumdadır (Çevrimiçi, kanalfinans.com).

Böylesine büyük ekonomik boyutu olan bir sektörde medya da önemli roller üstlenmektedir. Basın, bu ekonomiden kendisine düşen payı almak/artırmak arttırmak için çeşitli yol ve yöntemlere başvurmaktadır. Bu yöntemler bazen hem basının genel ilkeleriyle çelişmekte, hem de sporun aktörlerinin kimisine kazanç sağlarken kimisine de maddi ve manevi zararlar verebilmektedir.

Yukarıda paylaştığımız, spor basınında farklı zamanlarda yer alan asılsız haberler, spor kamuoyunda çeşitli şekillerde etki meydana getirmiştir. Bu etki kimi zaman gazetelere tiraj sağlamış, kimi zaman kulüplerin borsadaki hisselerini etkilemiş, kimi zaman kombine satışlarına katkı yapmıştır. 
Spor basını haber tercihi yaparken mesleki kıstaslardan ziyade, ekonomik çıkarlar ve beklentiler doğrultusunda haber ve yorumlar yayınlamaktadır. Bu konuyla ilgili 23 Ağustos 2011 tarihinde Ahmet Tekin imzalı www.cihandergi.com internet adresinde yayınlanan röportajda, Fotospor Gazetesi Eski Genel Yayın Yönetmeni Naci Arkan, gazete manşetlerinin tirajları nasıl etkilediğini çarpıcı bir şekilde açıklıyordu; "Fotospor Gazetesi'nin genel yayın yönetmeniyken gazetemin 425 bin civarında tirajı vardı. Beşiktaş'ı manşete çektiğim gün 100 bin, Galatasaray'ı manşete koyduğumuz gün de 50 bin tiraj kaybediyorduk. Fenerbahçe manşet olunca ise gazete normal satışını gerçekleştirirdi. Spor gazetesi çıkardığın için de mecburen diğer takımların haberlerini görmek ve manşete taşımak zorundasın, böyle olunca tiraj kaybı yaşanıyordu."

Spor basını bu kazancından olmamak, spor kamuoyuna ve spor ekonomisine yön vermek amaciyla zaman zaman asparagas haberlere yer vermektedir. Bunun neticesinde de kendilerine tiraj, sporun diğer unsurlarına da ekonomik anlamda etki etmektedirler. Mesela, Cardozo ile anlaşıldığı haberlerinin yapıldığı 15-22 Temmuz tarihleri arasında Fanatik gazetesi satışlarını bir önceki haftaya göre ortalama 10.367, Fotomaç gazetesi ise 13.151 adet arttırmıştır (Çevrimiçi, medyatava.com).

Beşiktaş'ın transfer etmek istediği ancak henüz sadece görüşmelerin yapıldığı her defasında Beşiktaş Kulübü tarafından israrla vurgulanmasına rağmen, transferi kesin olmuş gibi aktaran basın, görüşme yeri ve zamanı, ödeme şekli, sponsor desteklerinin tutarı gibi detaylar bile vermişti. Bu dönemde Beşiktaş'ın transfer etmek istediği Ronaldinho ile ilgili basında çıkan haberlerin yoğunlukta yer aldığ1 27 Aralık 2013 ile 7 Ocak 2014 tarihleri arasında, Beşiktaş'ın Borsadaki hissesi 1,69 seviyesinden 2,16'ya çıkarak yaklaşık yüzde 28 değer kazanmıştır.

22 Temmuz 2013 tarihli www.ahaber.com.tr internet sitesinde "Cardozo Bank" başlığıyla yayınlanan bir haber; "Paraguaylı yıldız, daha gelmeden servet kazandırdı. Menajerinin attığı Türkçe tweet'ler taraftarı heyecana boğarken, 72 saatte 2 bin 100 kombine satıldl, kasaya 3 milyon TL girdi. Transferi halinde piyasaya sürülecek Cardozo formalarnmn satışından ise 10 milyon TL gelir hedefleniyor." Şeklinde verilmiş, haberin devamında da, "Fenerbahçe'de Cardozo ile ilgili asıl proje ise '10 numara projesi'... Sarl-lacivertli kulüp bu hafta içerisinde imza atması beklenen Paraguaylı yıldıza 10 numaralı formayı verecek. Transfer gerçekleşirse, çarşamba günkü forma tanıtımında 10 numarayı Oscar Cardozo giyecek. Cardozo'nun formasından rekor satış ve büyük bir gelir hedefleyen Fenerium yetkilileri, 30 yaşındaki yıldızın adının yazılı olduğu formaları satışa sunmaya hazırlanıyor. Hedefi ise 100 binin üzerinde satış. Bu gerçekleşirse, Roberto Carlos'un 100 bin forma satışı rekoru kırılacak, kasaya 10 milyon TL girecek." diye ifade edilmişti.

Yukarıdaki örneklerden de anlaşılacağı üzere spor basınının spor ekonomisi üzerinde önemli etkisi vardır. Medya bu etki alanında etik ilkelerden bağımsız davranmamalı, doğru haberciliği esas almalı, kişi ve kuruluşlara kazanç sağlayacak yayın anlayışını benimsememelidir. Medyada etik anlayışının en fazla ihlal edildiği çalışma alanlarının başında spor basının geldiğini belirtmiştik. Türkiye'de spor basını, neredeyse etik anlayışının dışında bir gazetecilik alanı olarak görülmekte, meslek ilkelerine aykırı davranışlar etik bir bakış açısıyla tartışılmamaktadır. Oysa, etik 
ilkelere bağlılık, güvenilir bir basının temelini oluşturur. Basının işlevini yerine getirebilmesi ise ancak okuyucunun güven duymasıyla sağlanabilir. Gazetelerin spor sayfaları da bu olgudan bağımsız değildir (Uzun, 2004:1).

\section{SONUÇ}

Geçmişten günümüze, hem sporun medya üzerinde hem de medyanın spor üzerinde etkisi olduğu açıktır. Özellikle sporun tüm dünyada sosyal bir olgu kabul edilmesinde kitle iletişim araçlarının rolü büyüktür. Spor ve kitle iletişim araçlarının ilişkisi, yollarının kesiştiği ilk andan itibaren ivme kazanarak devam etmiş, giderek bir işbirliğine dönüşmüş ve bugün geldiğimiz noktada bu iki olgu birbirinden ayrı düşünülemez olmuştur. Sporun geniş kitlelere ulaşması, kitle iletişim araçlarına; televizyonlar açısından izleyici sayısının, gazeteler için satış rakamlarının artması şeklinde ekonomik bir değer katmıştır. Sporun medyaya sağladığı bu temel imkânlara karşın kitle iletişim araçları da sporun yaygınlaşmasını ve popülerlik kazanmasını sağlamıştır. Yazılı basınla başlayıp, radyolarla devam eden ve televizyonlarla birlikte zirveye ulaşan bu birliktelik artık bir bağımlılığa dönüşmüştür. Yeni medyanın spora dâhil olmasıyla daha da farklı konuma yükselmiştir.

Günümüz sporunun en önemli özelliği artık "pazarlanabilen" ve "para kazandıran" bir uğraş olmasıdır. Spor, sporculara büyük paralar, sponsor firmalara ya da spor kulübü yöneticilerine de büyük bir tanıtım ve itibar kazandırmaktadır. Büyük kitlelerin takip ettiği spor faaliyetleri, medya kuruluşlarının yayımlarında da büyük bir yer kaplamaktadır. Medya kuruluşları naklen yayınlar ve programlarla; ayırdıkları özel sayfalar ve eklerle sporu konu olarak işlerler. Bu karşılıklı ilgi ve arz sporu ve spor haberciliğini farklı boyutlara taşımıştır.

Sporu kazançlı bir noktaya taşıyan bu durum, sporun aktörlerinin, spor olaylarına bakışını da etkilemiştir. Kulüp yöneticileri bu durumu kendi lehlerine kullanmayı düşünmüştür. Medya da artık spor olaylarında ve spor kamuoyunda daha belirleyici ve daha etkin olmak istemiştir. Bu arzu medyada özellikle spor medyasında bir eksen kaymasına sebep olmuştur. Spor basını, meslek ilkelerini bir kenara bırakarak gazeteciliğin özüne aykırı içerikler oluşturmuş ve yayınlamıştır. Kitlelerin spora olaylarına karşı gün geçtikçe artan ilgisi dolayısıyla kitle iletişim araçları spor kamuoyunda daha fazla söz sahibi olmak, kitleleri yönlendirmek, daha fazla kazanç elde edebilmek için ilgi çekici, sansasyonel, heyecan verici vb. haberler üretmeye meyletmişlerdir. Kitlelerin artan ilgisiyle birlikte bu eğilim git gide abartı, asparagas ve yalan habere dönüşmeye başlamıştır.

Medya haber tercihini kitlenin bu ilgisi nedeniyle daha çok heyecan yaratan, ilgi uyandıran ve sansasyonel konulardan yana kullanmaya başlamıştır. Daha çok futbol odaklı ve dar bir alanda haber üretmek için çabalayan spor basını, kitleleri heyecanlandıracak haber bulamadığı zamanlarda da kendileri bu tarz haberler üretmeye başlamıştır. Asparagas olarak nitelendirilen bu habercilik anlayışı kitleleri zaman zaman heyecanlandirsa da uzun vadede hem sporun amacina ve ruhuna aykırılık teşkil etmekte, hem de basına olan güveni sarsmaktadır. Aslında haberciliğin diğer alanlarına da bulaşan bu tarz habercilik anlayışı, diğer alanlarda da basına olan 
güveni zedelemektedir. Örneğin, İstanbul Üniversitesi İletişim Fakültesi öğrencilerinden oluşan Akademedya grubunun yaptığ yüzde 86 'sı basına güvenmediğini ve basını saygın bulmadığını belirtmiştir.

Asparagas haberleri yayınlamayı giderek kanıksayan haberciler, yayınladıkları haberlerde iddia edildi, ortaya atıldı, öğrenildi vb. edilgen fiil ve cümle yapıları kullanarak, haberleri aklama veya kılıfına uydurma çabası içine girmektedirler. Ancak bu gibi uygulamalarla basına olan güvenin özellikle de spor basınına olan güvenin zedelenmesinin önüne geçilmesi mümkün değildir.

Genel anlamda medya ve spor medyası, herhangi bir kişi veya kuruluşa çıkar sağlama amacı gütmeden, haberleri bir veya birkaç kaynaktan doğrulatarak haber yapmalı, bünyesinde habercilik eğitimi almış, etik ilkeleri benimsemiş çalışan/çalışanlar bulundurmalı, her ne koşulda olursa olsun kamu yararına ve doğru habercilik yapmalıdır. Ayrıca futbol dışındaki spor dallarına ilgiyi artıracak yayınlara yer vermeli, kumar, şans oyunları gibi konularda da özendirici içerikte yayınlardan kaçınmalıdır.

İçerik bulma konusunda sorunlar yaşayan spor basını, oturduğu yerden kitlelerin de ilgisini çekecek haberler üreterek hem sayfalarını doldurmuş hem de tirajlarını artırmayı hedeflemiştir. Bunda da kısmen başarılı olmuşlardır. Ancak basının yazdığı haberlere güvenen ve basında yer alan haber ve bilgilere inanan/inanmak isteyen bir kitle mevcuttur. Bu kitle çoğu zaman hayal kırıklığına uğrasa da basında yer alan haberler spor kamuoyunu ve spor ekonomisini etkilemiştir. Yukarıda bahsettiğimiz üzere, gazetelerin satışlarının artmasının yanında, kulüplerin forma satışları, kombine gelirleri ve borsadaki hisseleri bu gerçek dişı ama heyecan verici haberlerden payına düşeni almıştır. Spor basını bu heyecanlı kitleyi daha sonra çeşitli şans oyunları haber ve yorumlarıyla elinde tutmak için çabalamış ve çabalamaya devam etmektedir.

\section{KAYNAKÇA}

Andrews, P. C. (2005). Sport Journalism: A Practical Guide, London: Sage Publication

Atalay, A. (2004). Spor, Medya ve Serbest Zaman, İstanbul: Beta Yayınevi

Balcıoğlu, İ.(2003). Sporun Sosyolojisi ve Psikolojisi. İstanbul: Bilge Yayınları

Barut, B. (2000). Haber Ve Yorum Düzleminde Türk Basınının Objektiflik Analizi, Fırat Üniversitesi Sosyal Bilimler Dergisi, Elazığ, 2000, Cilt: 10, Sayı: 2, s. 145-162

Çakır, H.(2008). Türk basınında ilk spor gazetesi "Futbol”, İletişim kuram ve araştırma dergisi, Sayı: 26 Kış-Bahar 2008

Çetin, E. (2015). Sporla İlgili Türk Basınında Yer Alan İlkyazı: Ali Ferruh Bey Ve "Eskrim" Makalesi, International Journal of Social Science, Number: 37, p. 149-157, Autumn I 2015

Döşyılmaz, E. (1998). Ülkemiz Spor Medyasının Toplum Üzerindeki Etkileri ve Sonuçları, Doktora Tezi, İstanbul; Marmara Üniversitesi Sağlık Bilimleri Enstitüsü 
İnce, M. (2016). Spor ile Siyasetin İlişkisi Üzerine Bir Analiz; Sporu Siyasete Alet Etmek, Karabük Üniversitesi Sosyal Bilimler Enstitüsü Dergisi, Yı1: 2016, Cilt: 6, Sayı: 2

İnuğur, N., (1992). Türk Basın Tarihi, İstanbul: Türkiye Gazeteciler Cemiyeti Yayını.

Kola, N., Kılıç, B. (2014)., aksiyon.com.tr./3 Ocak 1998 /Erişim Tar: 11.03.2014

Korkmaz, T.(1988). Yalan Haber Dosyası, Zaman Gazetesi Yayınları, İstanbul, No: 3

Megep, (2011). Milli Eğitim Bakanlığı, Gazetecilik, Spor Haberciliği ders notları, Ankara.

Nicholson, M. (2006). Sport and the Media: Managing the Nexus. Burlington: Elseiver Ltd.,

Özsoy, S., Sadık, R., ve Boz, H. (2011). Spor Dalı Çeşitliliği Bakımından Türkiye'deki Spor Gazetelerinin Avrupa'daki Spor Gazeteleri İle Karşılaştırılması, Gümüşhane Üniversitesi İletişim Fakültesi Elektronik Dergisi, Cilt: 2, Sayı: 1, Mart 2011, s.1

Özsoy, S.(2011). Spor Basını Açısından Türkiye'de 1950'den Günümüze Milliyet Gazetesi'nde Yaşanan Değişim, Spor Basını Açısından Türkiye'de 1950'den Günümüze..., Selçuk İletişim, Cilt:7, Sayı:1

Özsoy, S. (2011). Spor Gazetelerinin Başlıklarında Militarist Ve Şiddet İçerikli Metaforlar, Gümüşhane Üniversitesi İletişim Fakültesi Elektronik Dergisi, Sayı: 1, Mart 2011.

Öztürk, F. (1998). Toplumsal Boyutlarıyla Spor, Ankara; Bağırgan Yayınevi.

Savaş, İ. (1997). Spor Genel Kültürü. İstanbul: İnkılâp Kitabevi.

Sever, S. (Editör) (2012). Spor Ve Medya İlişkisi, T.C. Anadolu Üniversitesi Yayını No: 2656.

T.C. Millî Eğitim Bakanlığı, Spor Haberciliği Modülü, Ankara, 2011

Talimciler, A.(2010). Sporun Sosyolojisi, Sosyolojinin Sporu, İstanbul: Bağlam Yayıncılık

Uzun, R. (2004). Türkiye'de Spor Basınının Etik Anlayışı, İletişim Kuram ve Araştırmaları Dergisi, Yıl: 2004, Sayı; 19

Ünsal, B. ve Ramazanoğlu, F. (2013). Spor Medyasının Toplum Üzerindeki Sosyolojik Etkisi, Jret Eğitim ve Öğretim Araştırmaları Dergisi, Şubat 2013 Cilt:2 Sayı:1

"Medyalara Güvensizlik" İletişim Dünyası, 17 Ocak - Şubat 1994, s.3

Hürriyet, 8 Haziran 1998

Türkiye, 18 Temmuz, 2006

Fotomaç, 11 Ekim 2013

AMK, 31 Aralık 2013

Fotomaç, 27 Temmuz, 2013

\section{INTERNET}

Vikipedi, özgür ansiklopedi, Erişim Tar.: 06.03.2014

http://arsiv.gercekgundem.com/?p=571443

http://skorer.milliyet.com.tr/drogba-ve-sneijder-aslan-i-ucurdu/galatasaray/ detay/1742967/default.htm Erişim Tar.: 12.03.2014)

http://www.fanatik.com.tr/drogbada-kombine-hesabi_3_Detail_390_226579.htm 
http://www.sabah.com.tr/Spor/Futbol/2011/07/27/kartalda-kombine-soku http://www.hurriyet.com.tr/ ekonomi/22998694. asp

kanalfinans.com/yazarlar/tugba-ozay-turkiyede-futbol-ekonomisinin-buyuklugu-700-milyoneuroyu-asti

http://www.medyatava.com/tiraj/22-07-2013

http://spor.nedir.com/\#ixzz2vYsJqSCz Erişim Tar.: 10.03.2014

http://spor.nedir.com/\#ixzz2vYxa7UKW 